\title{
MENGUNGKAP MASA DEPAN: INOVASI PEMBELAJARAN BAHASA INDONESIA DALAM KONTEKS PENGEMBANGAN KARAKTER CERDAS
}

\author{
Atmazaki \\ Universitas Negeri Padang
}

\begin{abstract}
Abstrak
Artikel ini menjelaskan bagaimana inovasi dilakukan dalam pembelajaran bahasa Indonesia. Sebagai implementasi dari inkuiri dan kreativitas, inovasi dalam pembelajaran berkaitan dengan metode dan teknik pembelajaran. Para pengajar bahasa perlu berupaya agar pembelajaran bahasa mampu meningkatkan keterampilan berbahasa melalui berbagai metode dan teknik yang inovatif. Para pengajar perlu memahami dan terampil menggunakannya sesuai dengan dasar-dasar teorinya, tidak sekadar menyebut nama metode dan teknik itu.
\end{abstract}

Kata kunci: Inovasi; Pembelajaran bahasa; Karakter cerdas; Metode dan teknik

\section{PENDAHULUAN}

Di dalam Standar Isi (2006) mata pelajaran Bahasa Indonesia bertujuan agar peserta didik memiliki kemampuan (1) Berkomunikasi secara efektif dan efisien sesuai dengan etika yang berlaku, baik secara lisan maupun tulis; (2) Menghargai dan bangga menggunakan bahasa Indonesia sebagai bahasa persatuan dan bahasa negara; (3) Memahami bahasa Indonesia dan menggunakannya dengan tepat dan kreatif untuk berbagai tujuan; (4) Menggunakan bahasa Indonesia untuk meningkatkan kemampuan intelektual, serta kematangan emosional dan sosial (5) Menikmati dan memanfaatkan karya sastra untuk memperluas wawasan, budi pekerti, serta meningkatkan pengetahuan dan kemampuan berbahasa; (6) Menghargai dan membanggakan sastra Indonesia sebagai khazanah budaya dan intelektual manusia Indonesia.

Ruang lingkup mata pelajaran Bahasa Indonesia mencakup komponen kemampuan berbahasa dan kemampuan bersastra yang meliputi aspek-aspek sebagai berikut.

a. Mendengarkan: (1) menyadari bahwa mendengarkan adalah proses aktif dan konstruktif; (2) berlatih berperilaku sebagai pendengar yang aktif; (3) mendengarkan secara efektif dalam berbagai situasi untuk berbagai keperluan.

b. Berbicara (1) menyadari bahwa berbicara merupakan alat penting untuk berkomunikasi, berpikir, dan belajar; (2) berlatih berperilaku sebagai pembicara yang efektif; (3) berbicara dengan lancar dalam 
berbagai situasi untuk berbagai keperluan dan pendengar.

c. Membaca (1) menyadari bahwa membaca adalah proses yang aktif dan konstruktif; (2) berlatih berperilaku sebagai pembaca yang efektif dan strategis; (3) membaca dgn lancar dan percaya diri untuk berbagai teks dan keperluan.

d. Menulis (1) menyadari bahwa menulis adalah proses konstruktif dan berulang (recursive); (2) berlatih sebagai penulis yang efektif; (3) menulis dgn lancar dan percaya diri untuk berbagai keperluan dan pembaca, menggunakan format yang cocok.

Terlihat bahwa keberhasilan siswa mencapai tujuan-tujuan itu tidak saja akan menjadikan mereka menjadi pengguna bahasa yang efektif, tetapi juga akan memperlihatkan kecerdasan dalam berbahasa. Pada dasarnya, hal itulah yang dimaksud dengan karakter cerdas dalam artikel ini, yaitu kemantapan penggunaan bahasa yang memperlihatkan kecerdasan pemakainya.

Fakta lapangan menunjukkan bahwa tamatan sekolah menengah belum mampu berbahasa secara cerdas. Mahasiswa tahun pertama di berbagai perguruan tinggi selalu mengalami kesulitan dalam menuliskan tugas, menyampaikan pikiran dalam diskusi kelas, dan menarik informasi dengan cepat dari bacaan. Keadaan itu tentulah dampak dari buruknya kualitas pembelajaran bahasa Indonesia di sekolah.

Bagaimanakah meningkatkan kualitas pembelajaran bahasa Indonesia di sekolah? Jawabnya adalah inovasi!
Persoalannya, bagaimanakan inovasi tersebut dilaksanakan oleh guru (sekolah) agar mencapai "penggunaan bahasa yang cerdas" itu? Secara berturut-turut, artikel ini akan mendiskusikan tentang hakikat inovasi dan karakteristiknya, karakter (bangsa) cerdas dan implikasinya, dan metode pembelajaran bahasa yang mendukung kedua hal itu.

\section{PEMBAHASAN}

\section{INOVASI PEMBELAJARAN}

Inovasi adalah upaya "menerapan dan meningkatkan pengetahuan, ide-ide, metode, proses, dan alat baru yang mengarah ke produk, layanan, dan proses baru yang lebih baik" (Williams, 1999:17). Inovasi adalah tentang implementasi, bukan hanya ide-ide dan pengetahuan baru, tetapi juga ide dan pengetahuan yang diimpelentasikan. Model Williams (1999) di bawah ini menunjukkan bahwa penemuan (discovery dan invention), sebagai hasil kreativitas, mengarah pada proses dan

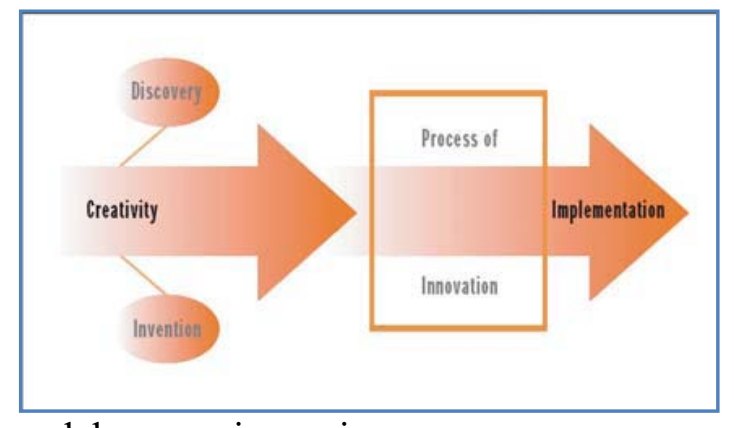

pelaksanaan inovasi.

Model Inovasi (William, 1999)

Model itu memperlihatkan bahwa inovasi dimulai dari penemuan (discovery and invention) dan berproses menjadi kreativitas. Hasil kreativitas itu berproses 
secara inovatif sehingga dapat diimplementasikan. Dengan demikian, inovasi mengandung makna yang luas tetapi jelas, yaitu penerapan hasil penemuan baru (implement of new invention).

Ada perbedaan penting antara "kreativitas" dan "inovasi," yang menjelaskan mengapa lingkungan sangat kreatif belum tentu menjadi tempat belajar yang sukses. Sementara kreativitas "menghasilkan ide-ide baru dan tepat dalam setiap bidang kegiatan manusia," (Teresa M. Amabile, 1997); inovasi adalah keberhasilan penerapan ide-ide itu yang diukur sebagai penciptaan nilai yang sebenarnya. Dalam pengalaman kita, masalah utama bukanlah ketiadaan ide-ide baru, tetapi ketidakmampuan mengubahnya menjadi sesuatu (produk, proses, pelayanan, dll) yang berarti.

Inovasi bisa besar atau kecil. Merekbaru atau hanya sedikit berbeda sudah dapat disebut inovasi. Namun inovasi dapat sangat kompleks seperti sistem ISO. Menurut West (dalam King \& Anderson 2002: 2--3) ciriciri inovasi adalah (1) produk, proses, atau prosedur nyata dalam suatu bidang; (2) harus baru bagi latar sosial tempat diperkenalkan, meskipun tidak selalu baru bagi individu yang memperkenalkannya; (3) harus disengaja, tidak insidental; (4) tidak harus merupakan perubahan yang rutin; (5) harus bertujuan untuk menghasilkan sesuatu yang manfaat; (6) harus terbuka dan berdampak kepada masyarakat. Hal itu berarti bahwa penemuan tidak berguna kecuali ditawarkan kepada masyarakat. Jika penemuan ini meningkatkan beberapa produk, proses, atau jasa untuk keperluan publik, penemuan itu berubah menjadi inovasi.

Kehadiran orang jenius dapat membantu inovasi--dapat mempercepat hasil akhir dengan memiliki orang yang bisa melihat dan membuat masa depan menjadi nyata. Namun, inovasi lebih dari karya dari seorang "Einstein." Inovasi melibatkan pengambilan karya seorang individu (atau tim) dari penemu dan membawanya ke masyarakat pengguna yang lebih luas. Inovasi dalam pembelajaran adalah upaya menerapkan penemuan-penemuan baru untuk meningkatkan proses dan hasil pembelajaran. Sudah tidak terhitung jumlah penemuan dalam pembelajaran, baik yang bernaung di bawah ideologi Behaviorisme, Kognitivisme, Humanisme, dan Konstruktivisme. Namun, karena kurang banyak guru yang bersedia bekerja keras untuk memahami, mengolah, dan menerapkan penemuan-penemuan baru itu maka inovasi dalam pembelajaran belum terlihat di Indonesia. Kita sering mendengar istilah seperti PAIKEM, CBSA, PPSI, RPP, dan beberapa istilah yang sesungguhnya adalah bentuk-bentuk inovasi yang dikembangkan pemerintah (Kemendiknas)

Mengapa inovasi diperlukan dalam pengajaran dan pembelajaran? Masa depan sekolah bergantung pada kemampuan masyarakatnya untuk berinovasi. Saat ini, persaingan semakin sengit; pengetahuan menyebar dengan cepat. Sekolah harus mampu melampaui praktik-praktik BIASA saat ini dan berkompetisi merealisasikan harapan masing-masing karena sangat penting untuk kelangsungan hidup sekolah (pembelajaran). 
Mitchell (2003) mengidentifikasi perlunya inovasi dalam pembelajaran. Inovasi dalam pembelajaran diperlukan apabila konteks global berubah. Konteks untuk pengajaran dan pembelajaran yang sedang berubah merupakan dampak dari faktor-faktor yang luas seperti ICT, perubahan dunia kerja, dan pendekatan belajar yang berpusat pada siswa. Kita tidak bisa sekadar diam menonton perkembangan dan perubahan yang terjadi dalam dunia global seperti itu. Kita perlu merebut dan menggunakannya agar tidak menjadi objek semata.

Sekolah memerlukan keragaman dan kreativitas yang terimplikasi dalam kinerja guru. Penemuan dalam bidang teknologi jangan membutakan guru, tetapi meraihnya untuk keperluan peningkatan pembelajaran. Dengan teknologi, guru tidak akan pernah lagi menyatakan kekurangan jam karena informasi dan aktivitas kelas dapat dipadatkan dan diterima siswa dengan lebih efektif. Oleh sebab itu, guru, sekali lagi GURU, harus meningkatkan pembelajaran mandiri dan belajar sepanjang hayat.

Inovasi dalam pengajaran merupakan respons terhadap pendorong perubahan yang berlipat ganda.

Penyebaran komunikasi digital meningkatkan kebutuhan akan melek teknologi informasi (TI) sehingga menantang sistem sekolah untuk mengintegrasikan IT ke dalam belajar di mana dan kapan hal itu relevan. Perubahan teknologi mengubah cara melaksanakan tugas dari yang normal dan hal ini sering meminta guru belajar lagi.

Berkurangnya horizon waktu menuntut perubahan cara belajar. Apa yang disebut belajar sepanjang hayat semakin menjadi tren. Para pekerja ingin meningkatkan pengetahuannya, sementara waktu utuk itu tidak tersedia. E-lerning adalah salah satu solusi dan hal itu menuntut guru untuk menguasai sistem e-learning. Semua itu akan mengubah budaya kerja guru dan sekolah dari "kapur dan papan tulis" ke "software dan computer".

Inovasi dalam mengajar diperlukan apabila kebijakan berubah. Perubahan kurikulum, pengembangan silabus, dan model-model pembelajaran sering terjadi. Belum sempat suatu perubahan tuntas dikuasai, kebijakan baru sudah datang lagi. Guru dan sekolah dikerubungi oleh kebijakan yang berubahubah sehingga membingungkan mereka. Namun bagi sekolah (guru) yang siap dalam menerima dan menerapkan inovasi tidak akan merasakan hal itu sebagai beban karena basis, sistem, dan kompetensi serta profesionalisme guru telah cukup handal. Intinya adalah kebiasaan "guru berceramah di ruang kelas" perlu diganti dengan penyediaan kemungkinan lain seperti perpustakaan, turorial, mentoring, dan modul-modul sebagai paket belajar mandiri.

Inovasi dalam mengajar dapat mencakup penyediaan layanan baru atau yang ditingkatkan sebagaimana

diinginkan siswa. Pengertian inovasi jarang ditemukan dalam literatur pendidikan, tetapi banyak dalam literatur bisnis. Namun pengertian dalam dunia bisnis itu dapat digunakan dalam dunia pendidikan seperti upaya memuaskan pelanggan dalam dunia bsinis dapat menjadi menyenangkan (PAIKEM) siswa dalam dunia pendidikan. 
Sehubungan dengan definisi inovasi dalam bisnis, ada tiga tren luas yang terlihat beberapa tahun terakhir. Kecenderungan pertama mendefinisikan inovasi dalam hal produk-produk yang dikembangkan, yang kedua mendefinisikan inovasi dalam hal cara staf berinovatif, dan ketiga dan yang terbaru, mendefinisikan inovasi dalam hal memberikan nilai bagi pelanggan (dalam dunia pendidikan adalah siswa) (Lin, 2001:10-11).

Inovasi dalam mengajar dapat mencapai tujuan (outcome) yang lebih baik bagi pelajar. Sebagai konsekuensi dari perubahan yang sedang berlangsung, inovasi yang lebih luas, lebih dalam, dan lebih sering diperlukan dalam praktik mengajar dan belajar saat ini. Secara khusus, fokus lebih tajam adalah pada pembelajaran yang mengarah ke hasil (pencapaian tujuan "outcome) dan kinerja yang lebih baik untuk pelajar, yaitu: (1) memastikan relevansi pengetahuan dan keterampilan dengan kehidupan sehari-hari; (2) memastikan layanan secara pribadi untuk setiap siswa, pembelajaran yang sesuai dengan gaya belajar siswa, bukan gaya mengajar guru; (3) memastikan pelayanan yang sesuai dengan konteks dan kebutuhan siswa.

Model belajar seumur hidup memberi alasan bagi guru untuk menjadi inovatif. Siswa perlu diaak untuk menjadi pembelajar seumur hidup. Burns (2002) menunjukkan bahwa pendidikan orang dewasa perlu menjauh dari "model pendidikan berbasis konten" berdasarkan kurikulum yang dirancang guru. Pesan ini, sulit didengar bagi banyak orang, adalah bahwa belajar seumur hidup dapat mengatasi strategi untuk abad kedua puluh satu (hal. 262-263). Belajar seumur hidup kemungkinan akan menjadi harapan atau suatu hak, yaitu hak untuk terus belajar sama pentingnya dengan hak untuk bekerja (hal. 263).

Burns mengusulkan bahwa model pendidikan untuk orang dewasa dan belajar sepanjang hayat harus diarahkan sendiri: dipilih sendiri, tujuan dan metode belajar ditetapkan sendiri, dihadapi sendiri, dan fleksibelilitas yang tinggi. Di samping itu, segala sesuatu yang terkait dengan peralatan belajar mudah dan ringan: bergerak bersama orang yang belajar; menyediakan pilihan untuk berhenti dan memulai lagi untuk belajar; tidak ada urutan tetap; tersedia apabila diperlukan; dirancang untuk kebutuhan khusus; dapat dimodifikasi karena perubahan keadaan; memungkinkan untuk berbagai modus / gaya belajar; memungkinkan untuk memperbesar peluang pendidikan dan kolaborasi (hal. 264).

Model ini akan menghasilkan pembelajar seumur hidup yang memiliki kemampuan untuk menetapkan tujuan realistis dan pribadi, menerapkan pengetahuan dan keterampilan secara efektif, mengevaluasi pembelajaran mereka sendiri, mencari informasi dari berbagai sumber, menggunakan strategi belajar yang berbeda untuk efek yang terbaik dalam situasi yang berbeda, menemukan konsep diri yang positif dan peningkatan rasa tanggung jawab terhadap diri sendiri dan orang lain (hal. 264).

Di masa mendatang, guru mungkin akan diminta untuk membantu siswa tidak hanya mengembangkan keterampilan teknis dan inti keterampilan generik, tapi keterampilan pribadi yang unik dan atribut 
yang dapat menyediakan kompetensi terbarukan untuk mengatasi masalah dunia kerja masa depan. Siswa juga bisa menggunakan keuntungan yang mereka peroleh untuk memulai atau merespons perubahan pribadi dan sosial dalam caracara yang lebih inovatif.

\section{Pengajaran inovatif dapat} melayani perbedaan individu siswa.

Melayani perbedaan individu siswa menjadi tujuan yang semakin penting bagi guru karena dorongan kontemporer untuk menjadi customer-centric. Untuk berbagai alasan, pendidikan telah semakin diwajibkan untuk mengenali dan menanggapi perbedaan individu siswa yang sebelumnya tidak terlihat di sektor ini. Burns (2000: 43-78) menunjukkan empat skema yang berbeda untuk menganalisis perbedaan individu siswa: (1) teori yang berhubungan dengan studi tentang ciri-ciri kepribadian dan pengaruh kepribadian pada perilaku, misalnya teori tentang introvert dan ekstrovert; (2) teori yang berkaitan dengan nilai-nilai dan preferensi, misalnya seorang siswa yang terbiasa dengan peran dominan guru mungkin menolak kesempatan belajar mandiri; (3) teori yang berkaitan dengan gaya pemikiran, misalnya teori Sternberg's tentang gaya berpikir legislatif, eksekutif. dan yudikatif; (4) pengalaman, misalnya teori tentang pengaruh memori pada pencapaian tujuan.

Untuk itu, guru dapat menggunakan Inventori Gaya Belajar yang dikembangkan oleh Kolb: accommodating, diverging, assimilating and converging, dan Kuesioner Gaya Belajar oleh Peter Honey dan Alan Mumford: activist, theorist, pragmatist, and reflector. Menurut Kolb sendiri (memperingatkan), penggunaan kategorisasi ini secara berlebihan merupakan ide yang buruk karena cenderung menstigmatisasi dan menstereotip siswa; mencegah mereka mengembangkan potensi sepenuhnya. Akan lebih efektif merancang kurikulum sehingga ada beberapa cara untuk siswa dari setiap gaya belajar untuk terlibat dengan topik, sehingga setiap jenis siswa memiliki cara awal untuk terhubung dengan materi, dan kemudian mulai meregangkan kemampuan belajarnya dalam mode belajar lainnya.

\section{PEMBANGUNAN KARAKTER BANGSA}

Di dalam naskah Kebijakan Nasional Pembangunan Karakter Bangsa (2010) dan Pengembangan Pendidikan Budaya dan Karakter Bangsa: Pedoman untuk Sekolah (2010) dinyatakan, “...karakter adalah nilai-nilai yang khas-baik (tahu nilai kebaikan, mau berbuat baik, nyata berkehidupan baik, dan berdampak baik terhadap lingkungan) yang terpateri dalam diri dan terejawantahkan dalam perilaku. Karakter secara koheren memancar dari hasil olah pikir, olah hati, olah raga, serta olah rasa dan karsa seseorang atau sekelompok orang. Karakter merupakan ciri khas seseorang atau sekelompok orang yang mengandung nilai, kemampuan, kapasitas moral, dan ketegaran dalam menghadapi kesulitan dan tantangan.

Secara psikologis karakter individu dimaknai sebagai hasil keterpaduan empat bagian, yakni olah hati, olah pikir, olah raga, olah rasa dan karsa. 
Karakter bangsa adalah

"kualitas perilaku kolektif

kebangsaan yang khas-baik yang

tecermin dalam kesadaran,

pemahaman, rasa, karsa, dan perilaku

berbangsa dan bernegara sebagai

hasil olah pikir, olah hati, olah rasa

dan karsa, serta olah raga seseorang

atau sekelompok orang. Karakter

bangsa Indonesia akan menentukan

perilaku kolektif kebangsaan

Indonesia yang khas-baik yang

tecermin dalam kesadaran,

pemahaman, rasa, karsa, dan perilaku

berbangsa dan bernegara Indonesia

yang berdasarkan nilai-nilai

Pancasila, norma UUD 1945, keberagaman dengan prinsip

Bhinneka Tunggal Ika, dan

komitmen terhadap NKRI."

Pembangunan Karakter Bangsa

adalah

"upaya kolektif-sistemik suatu

negara kebangsaan untuk

mewujudkan kehidupan berbangsa

dan bernegara yang sesuai dengan

dasar dan ideologi, konstitusi,

haluan negara, serta potensi

kolektifnya dalam konteks kehidupan

nasional, regional, dan global yang

berkeadaban untuk membentuk

bangsa yang tangguh, kompetitif,

berakhlak mulia, bermoral,

bertoleran, bergotong royong,

patriotik, dinamis, berbudaya, dan

berorientasi Ipteks berdasarkan

Pancasila dan dijiwai oleh iman dan takwa kepada Tuhan Yang Maha

Esa."
Pendidikan budaya dan karakter

bangsa adalah

"pendidikan yang mengembangkan

nilai-nilai budaya dan karakter pada

diri peserta didik sehingga menjadi

dasar bagi mereka dalam berpikir,

bersikap, bertindak dalam

mengembangkan dirinya sebagai

individu, anggota masyarakat, dan

warganegara. Nilai-nilai budaya dan

karakter bangsa yang dimiliki peserta didik tersebut menjadikan mereka sebagai warganegara Indonesia yang memiliki kekhasan dibandingkan dengan bangsa-bangsa lain.

Pembangunan karakter bangsa dilakukan secara koheren melalui proses sosialisasi, pendidikan dan pembelajaran, pemberdayaan, pembudayaan, dan kerja sama seluruh komponen bangsa dan negara. Adapun ruang lingkup sasaran pembangunan karakter bangsa meliputi: lingkup keluarga, lingkup satuan pendidikan, lingkup pemerintahan, lingkup masyarakat sipil, lingkup masyarakat politik, lingkup dunia usaha dan industri, dan lingkup media massa

Pengembangan karakter melalui pendidikan secara mikro dibagi dalam empat pilar, yakni kegiatan belajar-mengajar di kelas, kegiatan keseharian dalam bentuk pengembangan budaya satuan pendidikan; kegiatan ko-kurikuler dan/atau ekstra kurikuler, serta kegiatan keseharian di rumah dan masyarakat.

Artinya, perlu ada upaya terobosan terhadap kurikulum berupa pengembangan nilai-nilai yang menjadi dasar bagi pendidikan budaya 
dan karakter bangsa. Dengan terobosan kurikulum yang demikian maka nilai dan karakter yang dikembangkan pada diri peserta didik akan sangat kokoh dan memiliki dampak nyata dalam kehidupan dirinya, masyarakat, bangsa dan bahkan ummat manusia.

Pendidikan budaya dan karakter bangsa dilakukan melalui pendidikan nilainilai atau kebajikan (virtue) yang menjadi dasar budaya dan karakter bangsa.

Kebajikan yang menjadi atribut suatu karakter pada dasarnya adalah nilai. Oleh karena itu pendidikan budaya dan karakter bangsa pada dasarnya adalah pengembangan nilai-nilai yang berasal dari pandangan hidup/ideology bangsa Indonesia, agama, budaya, dan nilai-nilai yang terumuskan dalam tujuan pendidikan nasional.

Tujuan pendidikan budaya dan karakter bangsa adalah:

- mengembangkan potensi afektif peserta didik sebagai manusia dan warganegara yang memiliki nilai-nilai budaya dan karakter bangsa

- mengembangkan kemampuan peserta didik menjadi manusia yang mandiri, kreatif, berwawasan kebangsaan

- mengembangkan lingkungan kehidupan sekolah sebagai lingkungan belajar yang aman, jujur, penuh kreativitas dan persahabatan, serta dengan rasa kebangsaan yang tinggi dan penuh dignity.

Nilai-nilai yang dikembangkan dalam pendidikan budaya dan karakter bangsa diidentifikasi dari Agama, Pancasila, Budaya, dan Tujuan Pendidikan Nasional. Berdasarkan keempat sumber nilai tersebut maka dihasilkan sejumlah nilai untuk pendidikan budaya dan karakter bangsa, yaitu: religius, jujur, toleransi, disiplin, kerja keras, kreatif, mandiri, demokratis, rasa ingin tahu, semangat kebangsaan, cinta tanah air, menghargai prestasi, bersahabat/komunikatif, cinta damai, senang membaca, peduli sosial, dan peduli lingkungan.

Prinsip yang digunakan dalam pengembangan pendidikan budaya dan karakter bangsa adalah (1) berkelanjutan, (2) melalui semua mata pelajaran (saling menguatkan), muatan lokal, kepribadian, dan budaya sekolah, (3) nilai tidak diajarkan tapi dikembangkan, dan (4) dilaksanakan melalui proses belajar aktif .

Baik dilihat dari sudut pengertian, tujuan, maupun jalur dan sarana pembanguna karakter bangsa, mata pelajaran Bahasa Indonesia dapat memainkan peran yang sangat signifikan. Karakteristik pembelajaran Bahasa Indonesia yang membina keterampilan berbahasa melekat erat dengan pembangunan karakter yang cerdas yang merupakan poin penting dalam makalah ini. Orang yang terampil berbahasa akan memperlihatkan kecerdasan dan beberapa nilai yang dikembangkan dalam pembanguna karakter bangsa di atas. 


\section{INOVASI PEMBELAJARAN BAHASA}

\section{MASALAH KUNCI}

Adala beberapa masalah kunci yang perlu diingat guru.

1) Belajar suatu bahasa dan mengajarkan suatu bahasa adalah dua hal yang berbeda; baik guru maupun siswa harus merefleksikan fakta ini dan menyadari tanggung jawab bahwa mereka selalu berada dalam proses.

2) Metode pengajaran dan teknik pengajaran berbeda; metode mendeskripsikan filosofi guru tentang mengajar dan keseluruhan pendekatan terhadap kerja mereka; sementara teknik mengacu pada sesuatu yang dilakukan guru dari hari ke hari dalam bekerja dengan materi baru di dalam kelas.

3) Belajar suatu bahasa adalah aktivitas yang berpusat pada siswa dan hal itu menghendaki baik motivasi dari siswa maupun masukan input komprehensif dari sumber luar. Pelajar yang baik adalah yang aktif dan seorang yang peduli tanggungjawab dan peranannya sendiri dalam proses belajar.

4) Pengajaran bahasa adalah suatu proses ilmiah yang telah dipelajari dan diteliti secara luas sejak 60 tahun lalu. Ada cara yang baik dan buruk untuk mengajarkan suatu bahasa dan bagian tanggung jawab instruktur adalah memperbaharui keterampilannya sesering mungkin untuk merefleksikan cara-cara mengajar mutakhir dan mempunyai dampak positif terhadap siswa.

5) Sesuatu yang esensial adalah bahwa guru selalu mengingat bagaimana kelas berjalan: menyediakan kesempatan bagi siswa untuk belajar bahasa. Siswa ingin diberi kesempatan untuk berbicara dan praktik dan hal itu merupakan tujuan akhir. Siswa, dan bukan guru, yang harus menjadi pusat kualitas pengalaman belajar bahasa.

6) Belajar suatu bahasa adalah proses sepanjang hayat dan semua aspek berbahasa memerlukan revisi dan daur ulang secara konstan. Anda tidak pernah "selesai!" Hal ini berlaku baik untuk penutur asli maupun asing seperti kita menghadapi kosa kata baru dan konteks secara konstan untuk setiap katakata melalui hidup kita.

7) Setiap individu siswa mempunyai gaya belajar sendiri dan hal ini tidak akan berubah. Adalah tanggung jawab guru untuk selalu mempunyai pengetahuan seluas mungkin dan mencari variasi metode dan teknik pengajaran untuk setiap perbedaan siswa dan perbedaan gaya belajar mereka. 
8) Selain mempunyai gaya belajar yang berbeda, siswa juga mempunyai kebutuhan yang berbeda bergantung pada tempat mereka dalam proses belajar. Ini jelas terlihat pada siswa level rendah yang secara umum lebih beruntung berada dalam pelajaran yang terstruktur dan dengan motivasi eksternal. Sebaliknya, kita sering pula melihat bahwa siswa level yang lebih tinggi merasa lebih suka/beruntung berada dalam pengalaman belajar yang kurang terstruktur saat mereka dapat mengambil peran yang lebih aktif.

\section{AKTIVITAS DAN PENDEKATAN DI DALAM KELAS}

Memahami variasi metode pengajaran dan bagaimana metode-metode itu berubah sepanjang sejarah dapat membantu guru menyesuaikan pelajarannya dengan kebutuhan kelas. Ketika berbicara tentang suatu metode pengajaran, guru sering menanyakan beberapa pertanyaan penting dan mengapa hal itu penting untuk dipahami.

1) Mengapa saya perlu mengetahui berbagai metode pengajaran? Mempelajari berbagai metode pengajaran membantu guru merefleksikan cara mengajar mereka sendiri dan menilai kekuatan dan kelemahannya. Guru yang mengatahui dengan baik berbagai metode pengajaran tidak diragukan lagi akan menjadi guru yang lebih efektif.

2) Mengapa bisa mempelajari berbagai metode yang berbeda membantu saya di dalam kelas. Dengan memahami dan mampu menggunakan berbagai metode pengajaran, guru akan memungkinkan dirinya sendiri untuk menyesuaikan cara mengajarnya dengan kebutuhan siswa dan situasi kelas yang berbeda yang mungkin mereka temui di dalam mengajar.

3) Apa yang salah dengan metode tradisional yang digunakan oleh guru saya ketika dulu saya belajar bahasa? Pengajaran bahasa adalah suatu yang ilmiah dan penelitian terbaru yang secara konstan dikembangkan dapat memperluas dan meningkatkan kemampuan guru untuk mengajar secara efektif. Adalah tanggung jawab guru untuk mempelajari dan menggunakan metode mutakhir di dalam kelasnya supaya dapat memberikan keuntungan yang banyak bagi siswanya.

Dalam kenyataan, metode yang dipilih guru harus merefleksikan keyakinannya tentang bagaimana bahasa seharusnya dipelajari, latar belakang dan pengalamannya sendiri, dan, tentu saja, kebutuhan siswa di kelas. Ringkasan lima metode mutakhir di bawah ini tidaklah dimaksudkan agar guru merasa bahwa ia harus mengikutinya secara membabi buta 
satu metode, tetapi mengambil kekuatan unsur-unsur dari setiap metode itu untuk disesuaikan dengan situasi kelas tempat mereka mengajar.

\section{TINJAUAN METODE}

Banyak metode pembelajaran bahasa yang telah dikembangkan sejak berabad yang lalu. Berikut ini direviu beberapa metode inovatif dalam pembelajaran bahasa (Dardjowidjojo, 1987; Richards \& Rodgers, 1986; Omaggio, 1986).

Metode Terjemahan Tata bahasa berasal dari studi bahasa klasik seperti bahasa Yunani dan Latin dan hal itu telah dilakukan ratusn tahun lalu. Dengan menggunakan metode ini, guru mengasumsikan bahwa siswa mungkin tidak pernah membutuhkan untuk menggunakan bahasa, tetapi hanya mempelajari bahasa akan menjadi baik bagi mereka. Metode terjemahan tata bahasa menempatkan prioritas utama pada kemampuan membaca sastra dalam bahasa asing dan meneerjemahkan literatur itu secara akurat ke dalam bahasa pertama mereka.

Ciri ciri metode ini adalah sebagai berikut.

- Fokus kegiatan kelas adalah pada penjelasan aturan tata bahasa.

- Pengajaran dilakukan dalam bahasa pertama siswa, tidak dalam bahasa target.

- Kosa kata disajikan dalam daftar dua bahasa.

- Latihan kelas biasanya gramatikal dan fokus pada kontrol bentuk.
- Membaca dan menulis ditekankan dan sedikit waktu disediakan untuk berbicara dan mendengarkan.

Metode Audio-Lingual berkembang sekitar tahun 40-an di Amerika. Ide di belakang metode ini adalah bahwa siswa sangat baik belajar bahasa melalui pengulangan dan berlatih. Perhatian lebih diutamakan pada mendengarkan, dan penghafalan serta pengulangan. Metode ini tidak menekankan terjemahan karena diasumsikan bahwa bahasa pertama dan bahasa target mempunyai sistem tata bahasa yang berbeda dan terjemahan hanya akan membingungkan siswa.

Ciri ciri metode ini adalah sebagai berikut.

- Dialog adalah fitur utama kegiatan kelas.

- Dialog dipelajari, dihafal, dan diulang-ulang.

- Guru hanya berbicara dalam bahasa target dan memodelkan dialog secara berulang-ulang.

- Kesalahan dikoreksi secara langsung oleh guru.

- Substitusi dalam dialog dikontrol oleh guru.

Metode Respons Fisik Total dikembangkan tahun 60-an dan 70-an dan disebut TPR karena salah satu prinsipnya adalah bahwa siswa belajar lebih baik dan lebih cepat ketika mereka melibatkan bodi secara keseluruhan. Kelas TPR didasarkan atas serangkaian perintah yang diberikan oleh guru. Misalnya, guru akan berkata, "Berdiri" dan siswa mengikuti perintah itu. Metode ini menekankan kegiatan mendengarkan dan pemahaman dan 
memberi siswa sebanyak mungkin waktu yang mereka membutuhkan untuk mulai berbicara.

Ciri ciri metode ini adalah sebagai berikut.

- Dalam kelas TPR, siswa secara umum agak aktif dan terlibat dalam perintah yang harus diikuti.

- Guru berbicara relatif sedikit dan hanya dalam bahasa target.

- Sikap santai dan menyenangkan dan kesalahan ucapan dapat diterima.

- Siswa menyediakan waktu yang cukup banyak untuk mendengarkan sebelum mulai berbicara.

Pengajaran Bahasa Komunikatif merupakan metode mutakhir yang bagus dan dikembangkan sekitar tahun 90-an. Teori di belakang metode ini adalah bahwa sering siswa mampu melakukan tugas dengan baik dalam kelas, tetapi merasa sulit untuk berkomunikasi dalam dunia nyata. Oleh karena itu, tujuannya adalah membuat kelas bahasa semirip mungkin dengan dunia nyata. CLT juga menekankan penggunaan bahasa yang memadai. Hal itu berarti bahwa pengajaran bukan hanya "bagaimana berbicara" tetapi juga "apa yang dikatakan" dan "kapan mengatakannya."

Ciri ciri metode ini adalah sebagai berikut.

- Guru dan siswa hanya menggunakan bahasa target.

- Bahasa terget adalah alat komunikasi kelas tentang isu-isu nyata.
- Variasi ditekankan ketika mempelajari fungsi bahasa.

- Permainan dan bermain peran adalah biasa karena mirip dengan dunia nyatapenggunaan bahasa mempunyai tujuan.

- Penekanan diletakkan pada mendiskusikan situasi tempat jenis bahasa tertentu memadai.

- Kesalahan adalah biasa dan dapat diterima.

Metode Cara Diam (silent way) ini dikembangkan oleh Caleb Gattegno tahun 70-an. Ada dua komponen kunci untuk memahami metode pengajaran ini. Pertama, keyakinan Gattegno bahwa bagian yang sangat penting terjadi di dalam kelas adalah dalam belajar, TIDAK dalam mengajar; ia merasa bahwa siswa dapat dan harus bertanggung jawab penuh terhadap belajarnya sendiri. Kedua, sebagaimana diimplikasikan namanya, Cara Diam adalah metode yang menekankan guru diam di bawah prinsip bahwa diam dari guru mendorong independensi dan rasa percaya diri siswa.

Ciri ciri metode ini adalah sebagai berikut.

- Guru sangat jarang berbicara.

- Peta dan balok berwarna sering digunakan untuk melatih pengucapan.

- Gestur digunakan oleh guru untuk memperagakan bunyi baru.

- Guru tidak memuji atau mengeritik siswa karena hal itu tidak mendorong dan 
mengurangi rasa percaya diri siswa.

- Siswa dipaksa untuk belajar saling bersadar pada teman untuk umpan balik.

- Bahasa ibu siswa boleh digunakan untuk sesi umpan balik pada setiap akhir pelajaran.

\section{TINJAUAN TEKNIK}

Teknik berbeda dari metode karena berkaitan dengan masalah-masalah harian bagaimana guru memilih cara untuk menyajikan dan bekerja dengan material. Untuk menjaga kelas tetap menarik, guru perlu memilih dari berbagai metode di dalam kelas mereka. Sebagian siswa akan merespons diskusi kelompok dengan baik, sementara sebagian yang lain lebih suka sedikit tenang dalam aktivitas belajar. Penting bagi guru untuk membuat variasi komponen kunci pengajaran mereka. Menggunakan teknik yang berbeda di kelas dapat membuat kelas lebih menarik, membantu memotivasi siswa, dan mengakomodasi keragaman gaya belajar siswa.

Di bawah ini ada beberapa teknik umum untuk menyajikan pelajaran di kelas. Guru perlu bereksperimen dan menyesuaikannya dengan situasi kelasnya.

Teknik 1: Kuliah/Ceramah

Kuliah atau ceramah adalah bentuk presentasi yang biasanya digunakan untuk menyajikan informasi baru. Kuliah biasanya monolog seorang guru, tetapi ia juga termasuk kesempatan untuk mengajukan pertanyaan singkat dan diskusi. Kuliah bergantung sepenuhnya pada guru untuk konten dan informasi, dan hal ini merupakan aktivitas yang sepenuhnya berpusat pada guru. Hal ini akan berjalan dengan baik apabila guru mempunyai informasi untuk disajikan kepada siswa yang sama sekali baru dan tidak biasa bagi siswa.

Proses ceramah:

1. Memperkenalkan topikkatakan kepada siswa apa yang akan mereka dengar dan aktifkan minat mereka.

2. Menyajikan material.

3. Meringkaskan poin utama.

4. Memberi kesempatan untuk bertanya (optional).

Teknik 2: Dialog

Dialog adalah percakapan antara dua atau lebih peserta. Peserta-peserta ini bisa jadi guru atau siswa. Biasanya, dialog merupakan praktik dan mengulang untuk membantu siswa mengingat struktur atau kosa kata yang telah mereka pelajari. Dialog dapat dibaca dari teks atau material yang disiapkan oleh guru atau dihasilkan oleh siswa sendiri.

Proses dialog:

1. Peserta menghafal dialog secara diam.

2. Kelompok peserta mempraktikkan dialog itu bersama-sama, sering diulang.

3. Dialog dilanjutkan dari ingatan tanpa membaca.

4. Peserta memperluas dialog atau mengubahnya untuk disesuaikan dengan situasi mereka.

Teknik 3: Bermain Peran

Bermain peran adalah kegiatan yang dilakukan peserta dengan mengasumsikan peran orang lain daripada diri mereka 
sendiri. Mereka diminta untuk berpikir dan berbicara melalui karakter yang mereka perankan. Bermain peran sering digunakan untuk membantu peserta berpikir tentang berbagai sisi suatu masalah atau untuk mengurangi kecemasan dalam berbicara. Teknik ini berjalan dengan baik sebagai tindak lanjut dari dialog, siswa mengasumsikan peran-peran orang dari dialog itu dan menciptakan percakapan dirinya sendiri.

Proses bermain peran:

1. Ketua mengatur suatu konteks untuk bermain peran.

2. Peserta diberi peran dan waktu untuk berpikir tentang peran itu.

3. Beberapa jenis interaksi (debat, percakapan, dll) dilaksanakan antara peserta yang memerankan peran itu.

4. Peserta selesai memerankan dan mendiskusikan proses itu.

Teknik 4: Survei atau

Angket/Kuesioner

Teknik ini digunakan untuk memungkinkan peserta membentuk pertanyaan sendiri dan mengumpulkan informasi yang dibutuhkannya. Ini adalah teknik yang mempersyaratkan sedikit bimbingan dan secara keseluruhan diarahkan oleh peserta. Teknik ini baik untuk meningkatkan interaksi dan aktivitas siswa.

Proses angket/kuesioner:

1. Ketua menjelaskan informasi yang akan dikumpulkan.

2. Kelompok atau individu mengembangkan survei atau kuesioner untuk mengumpulkan informasi.
3. Survei atau kesioner dilengkapi di kelas.

4. Hasilnya dibagi dan didiskusikan.

Teknik 5: Diskusi Kelompok Kecil

Diskusi kelompok kecil digunakan apabila guru ingin mendorong interaksi dan penggunaan bahasa siswa. Teknik ini juga berguna untuk mengumpulkan opini dan ide siswa dan untuk mengurangi kecemasan berbicara di depan kelompok yang lebih besar. Di dalam kelas besar, biarkan berbagai kelompok kecil berkata-kata yang mungkin menimbulkan sedikit kebisingan, tetapi dalam kelas bahasa, kebisingan bagus!

Proses diskusi kelompok kecil:

1. Sebuah topik disajikan oleh guru.

2. Kelompok dibentuk dan pertanyaan diberikan.

3. Kelompok diberi waktu yang cukup untuk memperdebatkan atau mendiskusikan petanyaan.

4. Kelas bekerja bersama-sama untuk berbagi opini dan jawaban.

\section{Kebutuhan Siswa}

Kebutuhan siswa bervariasi menurut keakraban mereka dengan topik dan kepribadian mereka. Seperti dijelaskan sebelumnya, semua siswa berbeda dan, karena itu, semuanya mempunyai kebutuhan yang sedikit berbeda di kelas. Guru perlu mempertimbangkan baik materi/topik kelas maupun kepribadian siswa ketika merencanakan pelajaran. Tabel di bawah ini memperlihatkan beberapa kebutuhan yang 
dikaitkan dengantiga tipe siswa yang berbeda.

\begin{tabular}{|l|l|l|}
\hline \multicolumn{2}{|l|}{ Kebutuhan siswa } \\
\hline $\begin{array}{l}\text { Teriswat } \\
\text { Materi } \\
\text { dipersiapkan }\end{array}$ & $\begin{array}{l}\text { Siswa Tim } \\
\text { luar }\end{array}$ & $\begin{array}{l}\text { Siswa } \\
\text { Bebas }\end{array}$ \\
\hline $\begin{array}{l}\text { Pembelajaran } \\
\text { jelas }\end{array}$ & Berbagi & $\begin{array}{l}\text { Kurang } \\
\text { terstruktur } \\
\text { rendah }\end{array}$ \\
\hline $\begin{array}{l}\text { Kegiatan } \\
\text { terstruktur }\end{array}$ & Komunikasi & $\begin{array}{l}\text { Bebas } \\
\text { memilih } \\
\text { tugas }\end{array}$ \\
\hline $\begin{array}{l}\text { Penjelasan } \\
\text { teoretis }\end{array}$ & Kompromi & $\begin{array}{l}\text { Respek pada } \\
\text { orang lain }\end{array}$ \\
\hline $\begin{array}{l}\text { Umpan baik } \\
\text { guru }\end{array}$ & Terlibat & Kontrol \\
\hline Aman & $\begin{array}{l}\text { Kegiatan } \\
\text { fleksibel }\end{array}$ & $\begin{array}{l}\text { Guru yang } \\
\text { menantang }\end{array}$ \\
\hline $\begin{array}{l}\text { Memiliki } \\
\text { tujuan/arahan }\end{array}$ & fleksibel \\
\hline
\end{tabular}

Mudah dilihat dari tabel di atas bahwa kebutuhan siswa beragam secara signifikan bergantung pada tipe apa siswa itu. Ketika guru memikirkan metode dan teknik terbaik untuk diguakan di kelas adalah sesuatu yang esensial untuk mengingat kebutuhan siswa tersebut.

\section{Gaya Belajar Siswa}

Gaya belajar siswa adalah campuran berbagai elemen. Gaya belajar siswa sangat berbeda. Ada dua faktor yang tampil secara universal: siswa belajar apabila (1) mereka termotivasi dan (2) kecemasannya dikurangi. Penelitian juga menunjukkan bahwa siswa biasanya dibagi menjadi empat gaya belajar.

1) Siswa Imajinatif tertarik, terutama pada manka personal. Mereka suka berdiskusi, kerja kelompok dan umpan balik yang realistik tentang perasaan. Mereka belajar sangat baik dengan mendengarkan dan berbagi ide.

2) Siswa Analitis terutama tertarik dengan fakta. Mereka menyukai berpikir detil dan urutan yang terorganisasi. Mereka belajar sangat baik melalui ide-ide

3) Siswa Logis tertarik, terutama, tentang bagaimana sesuatu bejalan/terjadi. Mereka menyukai sesuatu yang teknis dan kegiatan tangan. Mereka belajar sangat baik dengan menguji teori dan menerapkan akal sehat.

4) Siswa Dinamis terutama tertarik dalam penemuan sendiri. Mereka suka variasi dalam metode pembelajaran. Mereka belajar sangat baik dengan cara coba-coba.

Dengan membagi siswa ke dalam empat kategori di atas, guru dapat memilih jenis kegiatan yang berbeda untuk disesuaikan dengan setiap gaya. Berikut ini adalah daftar empat tipe siswa yang dikompilasi Peace Corps oleh Mary Jo Larson. Guru dapat menggunakan ini ketika merencanakan pelajaran bersama tutor. 


\begin{tabular}{|c|c|}
\hline Tipe 1 & Tipe 3 \\
\hline $\begin{array}{l}\text { - } \text { mendiskusikan pengalaman probadi } \\
\text { - } \text { mendiskusikan suatu masalah } \\
\text { - } \text { melihat gambar, lukisan, poster, dan } \\
\text { - } \text { brainstorming } \\
\text { - } \text { mendengarkan tape } \\
\text { - menyanyikan lagu } \\
\text { - mewawancarai tamu } \\
\text { - } \text { menonton bermain peran dan lakon } \\
\text { - } \text { pendek } \\
\text { - } \text { pendek/ puisi } \\
\text { - } \text { berbagi model atau contoh tugas } \\
\text { pelajaran yang berlalu }\end{array}$ & $\begin{array}{l}\text { - } \text { membuat pertanyaan untuk dijawab orang } \\
\text { - lain } \\
\text { latihan yang meminta keterampilan } \\
\text { merpikir kritis (membadingkan, } \\
\text { mempriontraskan, menggeneralisasikan, } \\
\text { - menulis, merevisi, mengedit } \\
\text { - pilihan ganda /menjodohkan } \\
\text { - diskusi berpasangan atau kelompok } \\
\text { - merencakan proyek } \\
\text { - } \text { studi kasus } \\
\text { - latihan mengisi blank } \\
\text { - melengkapi dan melatih bermain peran } \\
\text { - melengkapi komik atau kartun } \\
\text { - membuat diagram, tabel, chart } \\
\text { - }\end{array}$ \\
\hline $\begin{array}{l}\text { - } \text { analisis deduktif } \\
\text { - } \text { kuliah } \\
\text { - drill terkontrol (metode audio-lingual) } \\
\text { - catatan kultural } \\
\text { - membaca dalam hati } \\
\text { - latihan terkontrol (metode audio-lingual) } \\
\text { - tata bahasa/ terjemahan } \\
\text { - dikte } \\
\text { - analisis diagram, tabel, dan chart }\end{array}$ & $\begin{array}{l}\text { - } \text { menulis surat } \\
\text { - } \text { mengorganisasi tema program } \\
\text { - } \text { membuat poster dan displai } \\
\text { - } \text { berbagi puisi, lagu, cerita, dan laporan asli } \\
\text { - } \text { berpidato } \\
\text { - } \text { berpartisipasi dalam skenario, lakon } \\
\text { - } \text { pendek, atau drama } \\
\text { - } \text { merpartisipasi dalam debat } \\
\text { - } \text { mengorganitkan karya siswa } \\
\text { - } \text { melaksanakan dan melaporkan } \\
\text { - } \text { mawancara } \\
\end{array}$ \\
\hline Tipe 2 & Tipe 4 \\
\hline
\end{tabular}

\section{Gaya Belajar dan Kurikulum/Silabus/RPP}

Pelajaran atau kurikulum yang ideal harus disesuaikan dengan semua gaya belajar untuk memastikan bahwa semua siswa mempunyai kesempatan yang sama untuk belajar. Untuk menggabungkan semua gaya belajar empat tahap berikut ini perlu disajikan dalam proses pembelajaran. 


\begin{tabular}{|c|c|c|}
\hline & Eksperimentasi Aktif & Observasi Reflektif \\
\hline 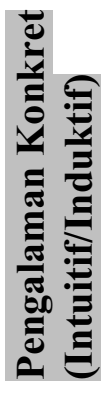 & $\begin{array}{l}\text { Produksi } \\
\text { (Siswa Dinamis) } \\
\text { kinestetik/audial }\end{array}$ & $\begin{array}{l}\text { Presentasi (Pengalaman) } \\
\text { (Siswa Imajinatif) } \\
\text { visual/audial }\end{array}$ \\
\hline 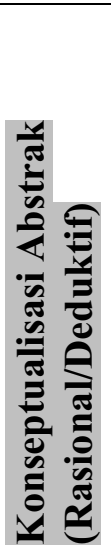 & $\begin{array}{l}\text { kinestetik/visual } \\
\text { Praktick } \\
\text { (Siswa Logis) }\end{array}$ & $\begin{array}{l}\text { visual/audial } \\
\text { Presentasi (Analisis) } \\
\text { (Siswa Analitis) }\end{array}$ \\
\hline
\end{tabular}

\section{SIMPULAN}

Inovasi dalam pembelajaran hendaknya didasarkan atas riset dalam bidang pembelajaran. Guru bahasa Indonesia perlu terus menrus melaksanakan riset apakah dalam bentuk eksperimen atau PTK untuk menemukan berbagai metode dan teknik dalam pembelajaran. Selain melaksanakan sendiri, guru juga dapat memanfaatkan riset orang lain. Banyak jurnal yang memuat hasil-hasil penelitian, banyak buku yang telah diterbitkan yang ditulis berdaarkan riset dalam pembelajaran. Kemauan guru mengembangkan diri adalah

awal inovasi pembelajaran yang sesungguhnya.

Pembelajaran bahasa Indonesia yang inovatif akan sangat membantu siswa mengembangkan keterampilan berbahasanya. Siswa yang terampil berbahasa akan terlihat cerdas. Namun kecerdasan saja tidak cukup. Diperlukan karakter lain yang melekat erat dengan keterampilan berbahasa seperti jujur, santun, dan lain-lain yang merupakan ciri-ciri orang berkarakteer cerdas. 


\section{DAFTAR PUSTAKA}

Amabile, T.M. 1997. "Motivating creativity in organizations: On doing what you love and loving what you do." California Management Review, 40, 39-58.

Atmazaki. 2009. "Orientasi Baru Pembelajaran Bahasa: Suatu Pendekatan Kreatif dan Kritis" (Makalah disajikan dalam seminar nasional pembelajaran di Universitas Asahan)

Atmazaki. 2009. "Peningkatan Kompetensi dan Profesionalitas Guru Seni Budaya dalam Konteks Revolusi Belajar" (Seminar Internasional Pendidikan Kesenian dengan Tema: "Meningkatkan Kompetensi dan Profesionalitas Guru dalam Pembelajaran Seni Budaya" di Jurusan Pendidikan Sendratasik FBSS UNP.

Billet, S. 2001. Learning in the Workplace, Allen \& Unwin, Maryborough.

Boud, D. \& Garrick, J. (ed.). 1999. Understanding Learning at Work, Spon Press, London.

Burns, R. 2002. The Adult Learner at Work, Business and Professional Publishing Pty Ltd, Warriewood, NSW.

Dardjowidjojo, Soenjono "Lima Pendekatan Mutakhir dalam Pengajaran Bahasa" dalam Soenjono Dardjowidjojo. 1987. Linguistik Teori dan Terapan. Jakarta: Lembaga Bahasa Unika Atma Jaya.

Drucker, P.F. 1999. Management Challenges for the Twenty-first Century, Butterworth \& Heinemann, Oxford.

Ellyard, P., 2001. 'Imagining the future and getting to it first', in Australian Institute of Management 2001. Innovation and Imagination at Work, McGraw Hill, Sydney.

Hager, P. 2001. 'Workplace judgement and conceptions of learning', Journal of Workplace Learning, Vol 13, No. 7/8, pp352-359. Imagination at Work, McGraw Hill, Sydney.

Kebijakan Nasiona Pembangunan Karakter Bangsa Tahun 2010-2025 (Pemerintah Republik Indonesia, 2001:7--8)

King, N. \& Anderson, N. 2002. Managing Innovation and Change, Thomson, Australia. Latchem, C. \& Hanna, D. (2001), Leadership for 21st Century Learning: Global Perspectives From Educational Innovators, Kogan Page, London.

Lin, I., 2001. 'Innovation in the networked world', in Australian Institute of Management dalam Innovation and Imagination at Work, McGraw Hill, Sydney.

Mant, A. 2002. 'Leadership in the Public Sector: Physics, Chemistry or Something Else Entirely', overhead slides, Building Leaders Managing People Seminar Series, Institute of Public Administration Australia, Melbourne, 25 Sept. 
Michael S. Slocum, Ph.D, The principal and chief executive officer of The Inventioneering Company. http://www.inventioneeringco.com .

Mitchell, J. G. 2003. E-business and Online Learning: Connections and Opportunities for VET, NCVER, Leabrook.

Mitchell, John. 2003. Emerging Futures: Innovation in Teaching and Learning in Vet. Melbourne: ANTA, Reframing the Future and Office of Training and Tertiary Education, VIC

Naskah Kebijakan Nasiona Pembangunan Karakter Bangsa Tahun 2010-2025 (Pemerintah Republik Indonesia, 2001:7--8)

Omaggio, Alice C. 1986. Language Teaching in Context. Boston: Heinle \& Heinle Publisher, Inc.

Pengembangan Pendidikan Budaya Dan Karakter Bangsa: Pedoman Sekolah Kementerian Pendidikan Nasional Badan Penelitian Dan Pengembangan Pusat Kurikulum Jakarta, 2010

Pengembangan Pendidikan Budaya Dan Karakter Bangsa: Pedoman Sekolah. Kementerian Pendidikan Nasional Badan Penelitian Dan Pengembangan Pusat Kurikulum Jakarta, 2010

Richards, Jack C. \& Rodgers, Theodore S. 1986. Approachs and Methods in Language Teaching. Cambridge: Cambridge University Press

Waterhouse, P., Wilson, B. \& Ewer, P. 1999. The changing nature and patterns of work and implications for VET, National Centre for Vocational Education Research, Leabrook, Australia.

William, A. 1999. Creativity, Invention, and Innovation. Sydney: Allen \& Urwin 